\title{
Hubungan Pengetahuan Dan Persepsi Ibu Balita Tentang Pelayanan Kesehatan Balita Selama Pandemi Covid 19 Dengan Pelaksanaan Tele Konsultasi Pelayanan Kesehatan Balita Di Kabupaten Banyumas
}

\author{
Sumarni $^{1^{*}}$, Fitria Prabandari ${ }^{2}$ \\ ${ }^{1}$ STIKes Muhammadiyah Gombong, Jalan Yos Sudarsio 461 Gombong Kebumen \\ Email: ${ }^{1}$ sumarni2880@gmail.com; ${ }^{2}$ fitriaprabandari30@gmail.com
}

Tanggal submisi:30 November 2020; Tanggal penerimaan: 20 Februari 2021

\begin{abstract}
Abstrak
Penyakit corona virus adalah penyakit menular yang disebabkan oleh virus Severe Acute Respiratory Syndrome Coronavirus-2 (SARS-CoV2). Pelayanan kesehatan pada bayi dan balita pada masa Covid-19 banyak mengalami perubahan disebabkan risiko penularan baik kepada bayi atau balita atau petugas kesehatan. Pelaksanaan pemantauan balita berisiko, pelayanan imunisasi, vitamin A, dilakukan dengan janji temu/ tele konsultasi/ kunjungan rumah. Tenaga kesehatan memberikan nomor teleponnya atau nomor fasilitas kesehatan yang dapat dihubungi untuk tele konsultasi atau janji temu jika anak memerlukan pemantauan atau pelayanan lebih lanjut. Penelitian ini bertujuan untuk mengetahui hubungan pengetahuan dan persepsi ibu terhadap pelaksanaan pelayanan kesehatan balita di Kabupaten Banyumas. Metode penelitian mengunakan metode kuantitatif. Jenis penelitian yang digunakan bersifat observasional dengan pendekatan cross sectional. Jumlah sampel pada penelitian ini sebanyak $30 \mathrm{ibu}$ dengan menggunakan teknik simple random sampling. Analisis data menggunakan uji chi Square. Hasil penelitian menunjukan ada hubungan antara pengetahuan ibu dengan pelaksanaan tele konseling pelayanan kesehatan balita pada masa pademik Covid-19 $(\mathrm{p}=0,000<\alpha(0,05))$ dan ada hubungan antara persepsi ibu dengan pelaksanaan tele konsultasi pelayanan kesehatan balita dengan nilai pada masa pademik Covid-19 $(\mathrm{p}=0,000<\alpha(0,05))$ Kesimpulan pada penelitian ini yaitu ada hubungan antara pengetahuan dan persepsi ibu dengan pelaksanaan tele konsultasi pelayanan kesehatan balita pada masa pandemik Covid-19.
\end{abstract}

Kata kunci : Pengetahuan, Persepsi, Tele Konsultasi

\begin{abstract}
Coronavirus is a contagious disease caused by the Severe Acute Respiratory Syndrome Coronavirus-2 (SARS-CoV 2) virus. Health services for infants and toddlers during the Covid-19 period experienced many changes due to the risk of transmission to either infants or toddlers or health workers. Monitoring under five at risk, immunization services, vitamin A, is carried out by appointment / tele consultation / home visit. Health workers provide their telephone numbers or health facility numbers that can be
\end{abstract}


contacted for tele consultations or appointments if the child requires further monitoring or services. This study aims to determine the relationship between knowledge and perceptions of mothers on the implementation of health services for children under five in Banyumas Regency. The research method uses quantitative methods. This type of research is observational with a cross sectional approach. The number of samples in this study were 30 mothers using simple random sampling technique. Data analysis using chi Square test. The results showed that there was a relationship between maternal knowledge and the implementation of telephoto counseling for toddler health services during the Covid-19 period $(\mathrm{p}=0.000<\alpha(0.05))$ and there was a relationship between maternal perceptions and the implementation of telephoto counseling for toddler health services with the value at Pademic Covid-19 $(\mathrm{p}=0.000<\alpha(0.05))$ The conclusion in this study is that there is a relationship between maternal knowledge and perceptions with the implementation of telephoto health service consultation for children under five during the Covid-19 pandemic.

Keywords: Knowledge, Perception, Tele Consultation

ISSN 1979-7621 (Print). ISSN 2620-7761 (Online).

DOI : $10.23917 /$ jk.v14i1.12748

\section{PENDAHULUAN}

Penyakit corona virus adalah penyakit menular yang disebabkan oleh virus Severe Acute Respiratory Syndrome Coronavirus-2 (SARS-CoV2). Penyakit ini ditularkan melalui manusia ke manusia dimana sebagian besar orang yang terinfeksi (Covid-19) akan mengalami penyakit pernapasan ringan hingga sedang dan sembuh tanpa memerlukan perawatan khusus WHO sejak 11 Maret 2020 telah menetapkan covid- 19 sebagai pandemi global dimana terdapat lebih dari 118.000 kasus di 114 negara dan 4291 orang telah meninggal dunia. Indonesia sendiri menetapkan penyakit Covid-19 sebagai bencana nasional sejak 14 maret 2020. Kasus Covid-19 di Jawa Tengah sampai bulan Juni 2020 berjumlah 4.631 terdiri dari $1.945(42,00 \%)$ positif dirawat, $2.295(49,56 \%)$ positif sembuh dan $391(8,44 \%)$ positif meninggal. (Kemenkes RI, 2020)

Kabupaten Banyumas merupakan salah satu kabupaten yang mengalami kasus Covid-19 tinggi di Jawa Tengah. Berdasarkan data jumlah kasus Covid-19 terkonfirmasi positif sampai bulan juni 2020 berjumlah 88 kasus, yang terdiri dari 67 kasus sembuh, 4 kasus meninggal dunia dan 17 kasus masih di rawat. (Dinkesprov, 2020)

Covid-19 ditularkan melalui kontak erat dan droplet, kecuali jika ada tindakan medis yang memicu terjadinya aerosol (seperti bronkoskopi, nebulisasi dan lain lain) dimana dapat memicu terjadinya risiko penularan melalui airborne. Individu yang paling berisiko terinfeksi adalah mereka yang mengalami kontak erat dengan pasien Covid19 atau petugas kesehatan yang merawat pasien Covid-19

Pelaksanaan pelayanan kesehatan pada masa pandemi Covid-19 banyak mengalami perubahan disebabkan adanya risiko penularan. Salah satu perubahan yang terjadi adalah pelayanan kesehatan pada bayi dan balita. Pelayanan kesehatan pada bayi dan balita sehat terdiri dari imunisasi, pemantauan tumbuh kembang, dan deteksi dini kelainan/masalah kesehatan. Sedangkan asuhan kesehatan balita sakit antara lain 
pemeriksaan fisik dan penunjang serta tindakan sesuai dengan kondisi balita.

Pelayanaan kesehatan pada balita di masa pandemi covid 19 antara lain: Usahakan membuat janji temu dengan pemberi pelayanan agar tidak menunggu terlalu lama, menggunakan masker baik ibu maupun anak sejak dari rumah, upayakan tidak menggunakan transportasi umum, langsung cuci tangan dengan sabun dan air mengalir begitu sampai di fasilitas pelayanan kesehatan, jaga jarak minimal 1,5 m dengan orang sekitar dan upayakan tidak menyentuh apapun jika tidak diperlukan, selesai pelayanan segera kembali ke rumah, ikuti protokol tatacara masuk rumah setelah berpergian (segera mandi dan ganti baju). (Kemenkes RI, 2020)

Menurut Notoadmojo, S (1993) faktor yang mempermudah atau mempredisposisi terjadinya perilaku seseorang antara lain pengetahuan, sikap, keyakinan, kepercayaan, nilai-nilai dan tradisi. Pengetahuan dapat membentuk keyakinan tertentu sehingga seseorang berperilaku sesuai dengan keyakinan tersebut dengan pengetahuan kesehatan lingkungan yang baik diharapkan dapat meningkatkan kesadaran masyarakat akan pentingnya menciptakan kondisi lingkungan yang sehat, sehingga dapat memutuskan rantai penularan penyakit melalui lingkungan serta perilaku hidup bersih dan sehat agar tidak mudah tertular penyakit.

Begitu pula dengan pengetahuan yang baik tentang pelayanan kesehatan balita selama masa pandemic Covid 19 akan memberikan persepsi yang baik kepada ibu balita sehingga mampu mempengaruhi prilaku ibu balita dalam melakukan upaya memperoleh pelayanan kesehatan bagi balita. Definisi Operasional Variabel
Pengetahuan dan persepsi yang baik tentang pelayanan kesehatan balita selama masa pandemic covid 19 berpengaruh terhadap keberhasilan upaya pencegahan penularan covid 19 pada pelayanan kesehatan balita oleh ibu dan keluarga.

Penelitian ini membahas tentang pengetahuan dan persepsi ibu balita terkait dengan pelayanan tele konsultasi kesehatan balita, hal ini menyikapi kebijakan pemerintah dalam mengurangi penularan covid 19 pada pelayanan asuhan balita. Oleh karena itu penelitian ini belum pernah dilakukan sebelumnya, hanya merujuk pada penelitian tentang hubungan pengetauan dan persepsi terhadap prilaku. Hipotesis dalam penelitian ini adalah ada hubungan antara pengetauan dan persepsi ibu balita terdapat pelayanan tele konsultasi kesehatan balita.

Penelitian ini bertujuan untuk mengetahui hubungan pengetahuan dan persepsi ibu balita tentang tele konseling pelayanan kesehatan balita di masa pandemic Covid 19 terhadap pelaksanaan pelayanan tele konsultasi kesehatan balita di Kabupaten Banyumas.

\section{METODE PENELITIAN}

Penelitian ini mengunakan metode kuantitatif. Jenis penelitian yang digunakan bersifat observasional dengan pendekatan cross sectional. Populasi dalam penelitian ini adalah seluruh ibu balita yang di desa Pasir Lor kecamatan Karanglewas kabupaten Banyumas sebanyak 290 Balita, besar sampel pada penelitian ini diperoleh sebanyak $30 \mathrm{ibu}$ balita. Pengumpulan data menggunakan kuesioner pengetahuan, persepsi dan pelaksanaan pelayanan kesehatan balita pada massa pandemi covid 19. 
Tabel 1. Definisi Operasional

\begin{tabular}{|c|c|c|c|}
\hline No & Variabel & Pengertian & Skala \\
\hline 1 & Pengetahuan & $\begin{array}{l}\text { Pengetahuan ibu balita tentang pelayanan } \\
\text { kesehatan balita pada masa Pandemi Covid } \\
19\end{array}$ & $\begin{array}{l}\text { Ordinal } \\
\text { Kriteria } \\
\text { 1. Baik } \\
\text { 2. Cukup } \\
\text { 3. Kurang baik. }\end{array}$ \\
\hline 2 & Persepsi & $\begin{array}{l}\text { Persepsi/keyakinan ibu balita tentang } \\
\text { pelayanan kesehatan balita pada masa } \\
\text { pandemi Covid } 19\end{array}$ & $\begin{array}{l}\text { Ordinal } \\
\text { Kriteria: } \\
\text { 1. Baik } \\
\text { 2. Cukup } \\
\text { 3. Kurang baik. }\end{array}$ \\
\hline 3 & $\begin{array}{l}\text { Pelaksanaan } \\
\text { pelayanan telel } \\
\text { konsultasi kesehatan } \\
\text { Balita }\end{array}$ & $\begin{array}{l}\text { Pelaksanaan pelayanan kesehatan balita } \\
\text { pada masa pandemic Covid } 19 \text { melalui } \\
\text { media elektronik seperti SMS, Whatsapp, } \\
\text { dll. }\end{array}$ & $\begin{array}{l}\text { Nominal } \\
\text { 1. Melakukan } \\
\text { 2. Tidak melakukan }\end{array}$ \\
\hline
\end{tabular}

Analisis yang digunakan pada penelitian ini adalah dengan menggunakan uji chi Square untuk mengetahui hubungan pengetahuan dan persepsi ibu balita tentang pelayanan kesehatan balita pada masa pandemic covid 19 terhadap pelaksanaan tele konsultasi pelayanan kesehatan balita.

\section{HASIL DAN PEMBAHASAN}

Pengetahuan ibu balita tentang pelayanan kesehatan balita di masa pandemic Covid 19

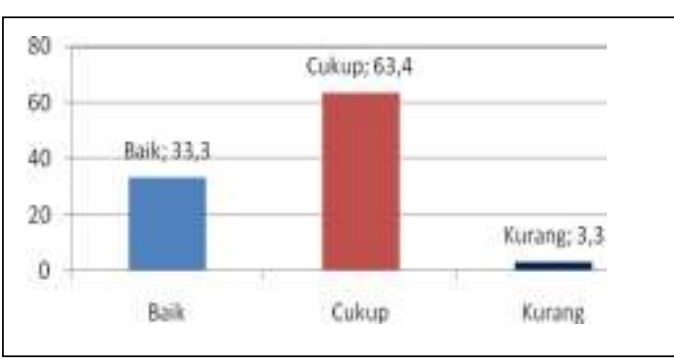

Gambar 1. Diskripsi Pengetahuan Ibu Balita tentang pelayanan kesehatan balita di masa pandemic Covid 19

Berdasarkan hasil penelitian pada Gambar 1 diatas menunjukan bahwa sebanyak $63,4 \%$ ibu balita mempunyai pengetahuan cukup tentang pelayanan kesehatan balita di masa pandemic Covid 19.

Hal ini dipengaruhi oleh mudahnya akses informasi tentang Covid 19 baik melalui social media maupun melalui televise, namun informasi yang diperoleh masih bersifat umum tentang pencegahan covid 19 dan masih ada beberapa informasi penting tentang pelayanan kesehatan pada balita di masa pandemic covid 19 belum diketahui oleh ibu balita. Oleh karena itu perlu sekali sosialisasi dari tenaga kesehatan dan pemerintah tentang pelayanan balita di masa covid 19.

Hal ini sesuai dengan teori menurut Soekanto (2002) mengatakan ada beberapa faktor yang mempengaruhi pengetahuan dalam masyarakat, salah satunya adalah informasi. Seseorang yang mempunyai sumber informasi yang lebih banyak akan mempunyai pengetahuan yang lebih luas. Informasi dapat diperoleh dari majalah, surat kabar, radio, dan televisi.

Persepsi ibu balita tentang pelayanan kesehatan balita di masa pandemic Covid 19 


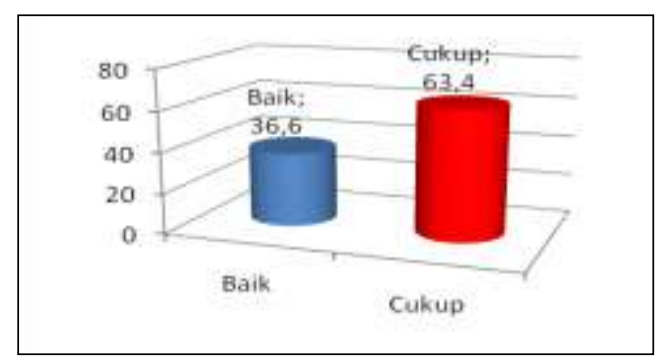

Gambar 2. Diskripsi Persepsi Ibu Balita tentang pelayanan kesehatan balita di masa pandemic Covid 19

Berdasarkan hasil penelitian pada Gambar 2 diatas menunjukan bahwa gangguan kejiwaan, nilai dan kebutuhan juga minat, dan motivasi dan faktor eksternal yaitu meliputi; latar belakang keluarga, informasi yang diperoleh, pengetahuan dan kebutuhan sekitar, intensitas, ukuran, keberlawanan, pengulangan gerak, hal-hal baru dan familiar atau ketidak asingan suatu objek.

Pelaksanaan tele konsultasi pelayanan kesehatan balita pada masa pandemic Covid 19 di Kabupaten Banyumas.

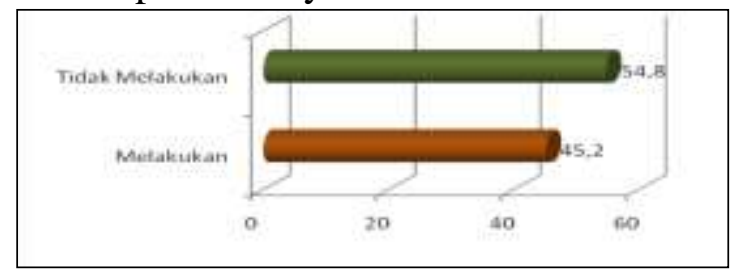

Gambar 3. Diskripsi Pelaksanaan tele konsultasi pelayanan kesehatan balita pada

Menurut Lawrence Green (1991) dalam Nursalam (2014), kesehatan seseorang atau masyarakat dipengaruhi oleh dua faktor pokok yaitu faktor perilaku (behavior causes) dan faktor diluar perilaku (non- behavior causes). Sementara faktor perilaku (behavior causes) dipengaruhi oleh tiga faktor yakni : faktor predisposisi (Predisposing Factors) yang meliputi umur, pekerjaan, pendidikan, pengetahuan dan sikap, faktor pemungkin (Enabling Factors) yang terwujud dalam sebanyak 63,4\% ibu balita mempunyai persepsi cukup tentang pelayanan kesehatan balita di masa pandemic Covid 19.

Hal ini dipengaruhi banyak faktor antara lain banyaknya informasi yang tersedia tentang covid baik melalui media televise maupun meia online. Menurut Miftah Toha (2003), faktor-faktor yang mempengaruhi persepsi seseorang adalah sebagai berikut : faktor internal antara lain; perasaan, sikap dan kepribadian individu, prasangka, keinginan atau harapan, perhatian (fokus), proses belajar, keadaan fisik,

\section{masa pandemic Covid 19 di Kabupaten Banyumas.}

Berdasarkan hasil penelitian pada Gambar 3diatas menunjukan bahwa sebanyak 54,8 \% ibu balita memilih untuk tidak melakukan tele konsultasi pelayanan tentang kesehatan balita di masa pandemic covid 19.

Hal ini dikarenakan tele konsultasi merupakan metode baru dalam pelayanan kesehatan dan ibu balita belum terbiasa dan masih merasa bahwa pelayanan langsung dengan tatap muka merupakan pelayuanan yang paling diharapkan dan menimbulkan kepuasan tersediri bagi ibu balita. Hal ini dikarenakan dengan tatap muka lebih mudah berinteraksi dan mendapatkan respon langsung dari tenaga kesehatan terkait permasalahan yang dihadapi oleh ibu balita. lingkungan fisik dan jarak ke fasilitas kesehatan, dan faktor penguat (Reinforcing Factors) yang terwujud dalam dukungan yang diberikan oleh keluarga maupun tokoh masyarakat (Notoatmodjo, 2014).

3.1 Hubungan pengetahuan ibu balita tentang pelayanan kesehatan balita di masa pandemic Covid 19 terhadap pelaksanaan tele konsultasi pelayanan kesehatan balita di Kabupaten Banyumas. 


\begin{tabular}{|c|c|c|c|c|c|c|c|}
\hline \multirow[t]{2}{*}{ Katagori } & \multicolumn{2}{|c|}{ Melakukan } & \multicolumn{2}{|c|}{$\begin{array}{l}\text { Tidak } \\
\text { Melakukan } \\
\end{array}$} & \multicolumn{2}{|c|}{ Jmh } & \multirow{2}{*}{$\begin{array}{l}\mathbf{p} \\
0,000\end{array}$} \\
\hline & f & $\%$ & f & $\%$ & f & $\%$ & \\
\hline Baik & 7 & 70 & 3 & 30 & 10 & 33,3 & \\
\hline Cukup & 6 & 31,6 & 13 & 68,4 & 19 & 63,4 & \\
\hline Kurang & 1 & 100 & 0 & 0 & 1 & 3,3 & \\
\hline Jumlah & 14 & 45,2 & 16 & 54,8 & 30 & 100 & \\
\hline
\end{tabular}

Tabel 1. Hubungan pengetahuan ibu terhadap pelaksanaan tele konsultasi pelayanan kesehatan balita di Kabupaten Banyumas.

Berdasarkan tabel 1, menunjukan bahwa pengetahuan ibu tentang pelayanan kesehatan balita di masa pademik covid 19 sebanyak $70 \%$ mempunyai pengetahuan baik dan memilih melakukan pelayanan tele konsultasi kesehatan balita di masa pandemic covid 19, sedangkan $68,4 \%$ ibu balita yang mempunyai pengetahuan cukup memilih tidak melakukan pelayanan tele konsultasi kesehatan balita dan sebagian besar memilih menunda memeriksakan kesehatan balita.

Hasil uji statistik Chi-Square pengetahuan ibu tentang pelayanan kesehatan balita di masa pandemic Covid 19 terhadap pelaksanaan tele konsultasi pelayanan kesehatan balita didapatkan nilai $\mathrm{p}=0,000$ dengan tingkat signifikasi 0,05. Maka dapat disimpulkan bahwa HO ditolak yang berarti terdapat hubungan pengetahuan ibu tentang pelayanan kesehatan balita di masa pandemic Covid 19 terhadap pelaksanaan tele konsultasi pelayanan kesehatan balita di Kabupaten Banyumas.

Hal ini sesuai dengan penelitian menurut Darmawan A. (2016), orang tua yang berpengetahuan baik mempunyai peluang 2,042 kali untuk berperilaku baik dalam memanfaatkan pelayanan posyandu dibandingkan dengan orang tua yang berpengetahuan kurang. Hasil penelitian ini sejalan dengan penelitian yang dilakukan oleh Purnawati (2014) yang bertujuan untuk mengetahui pengaruh faktor umur terhadap kunjungan lansia dalam kegiatan posyandu terhadap lansia sebanyak 73 responden. Dalam penelitian ini menunjukkan bahwa proporsi lansia yang berpengetahuan baik lebih besar untuk melakukan kunjungan ke posyandu dibandingkan dengan lansia yang berpengetahuan kurang dan dari hasil uji statistik diperoleh nilai $\mathrm{p}=0,001$ artinya terdapat hubungan antara pengetahuan dengan kunjungan lansia dalam kegiatan posyandu $(p<0,05)$.

3.2 Hubungan persepsi ibu balita tentang pelayanan kesehatan balita di masa pandemic Covid 19 terhadap pelaksanaan tele konsultasi pelayanan kesehatan balita di Kabupaten Banyumas.

Tabel 2. Hubungan persepsi ibu balita tentang pelayanan kesehatan balita di masa pandemic Covid 19 terhadap pelaksanaan tele konsultasi pelayanan kesehatan balita di Kabupaten Banyumas.

\begin{tabular}{lccccccc}
\hline \multicolumn{1}{c}{ Katagori } & \multicolumn{2}{c}{ Melakukan } & \multicolumn{2}{c}{$\begin{array}{c}\text { Tidak } \\
\text { Melakukan }\end{array}$} & Jumlah & p \\
\cline { 2 - 6 } & $\mathbf{f}$ & $\%$ & $\mathbf{f}$ & \% & f & $\%$ & 0,000 \\
\hline Baik & 5 & 45 & 6 & 55 & 11 & 36,6 & \\
\hline Cukup & 9 & 47,4 & 10 & 52,6 & 19 & 63,4 \\
\hline Jumlah & 14 & 45,2 & 16 & 54,8 & 30 & 100 & \\
\hline
\end{tabular}


Berdasarkan Tabel 2, menunjukan bahwa persepsi ibu tentang pelayanan kesehatan balita di masa pademik covid 19 sebanyak 55\% mempunyai persepsi baik dan memilih tidak melakukan tele konsultasi pelayanan kesehatan balita di masa pandemic covid 19, sedangkan 52,6 ibu balita yang mempunyai pengetahuan cukup juga memilih tidak melakukan pelayanan tele konsultasi kesehatan balita dan sebagian besar memilih menunda memeriksakan kesehatan balita.

Hasil uji statistik Chi-Square persepsi ibu balita tentang pelayanan kesehatan balita di masa pandemic Covid 19 terhadap pelaksanaan pelayanan kesehatan balita didapatkan nilai $p=0,000$ dengan tingkat signifikasi 0,05. Maka dapat disimpulkan bahwa H0 ditolak yang berarti terdapat hubungan persepsi ibu balita tentang pelayanan kesehatan balita di masa pandemic Covid 19 terhadap pelaksanaan tele konsultasi pelayanan kesehatan balita di Kabupaten Banyumas.

Hal ini dikarenakan pelayanan langsung atau tatap muka lebih memberikan rasa puas kepada ibu balita karea dapat menerima respon secara langsung terkait masalah kesehatan balita.

Hasil uji statistik Chi-Square persepsi ibu balita tentang pelayanan kesehatan balita di masa pandemic Covid 19 terhadap pelaksanaan pelayanan kesehatan balita didapatkan nilai $\mathrm{p}=0,000$ dengan tingkat signifikasi 0,05. Maka dapat disimpulkan bahwa H0 ditolak yang berarti terdapat hubungan persepsi ibu balita tentang pelayanan kesehatan balita di masa pandemic Covid 19 terhadap pelaksanaan pelayanan kesehatan balita di Kabupaten Banyumas.

Hasil penelitian ini juga sejalan dengan hasil penelitian Darmawan, A. (2016) bahwa pemanfaatan pelayanan posyandu di Desa Pemecutan Kelod lebih baik pada orang tua yang memiliki sikap baik dibandingkan dengan orang tua yang bersikap kurang terhadap posyandu. Orang tua yang memiliki sikap baik terhadap posyandu mempunyai peluang 1,408 kali untuk memanfaatkan pelayanan posyandu lebih baik dibandingkan dengan orang tua yang memiliki sikap kurang terhadap posyandu.

Menurut Newcomb dalam Notoatmodjo (2014 ), menyatakan bahwa sikap adalah kesiapan atau kesediaan seseorang untuk bertindak (belum merupakan suatu tindakan). Selain itu, sikap seseorang dalam berperilaku juga dipengaruhi oleh pengetahuan yang dimilikinya, dimana semakin tinggi tingkat pengetahuan seseorang akan suatu hal maka semakin baik pula sikap yang dimilikinya akan hal tersebut (NotoatmodjO, 2014).

Menurut Mar'at (1981) dalam Suryaningsih (2012) bahwa sikap dapat dibentuk dengan propaganda yaitu suatu teknik atau usaha yang dilakukan oleh seseorang secara sistematis dan sungguhsungguh dipikirkan secara mendalam untuk mempengaruhi pendapat atau sikap yang dimiliki oleh orang lain. Bentuk propaganda ini bisa berupa isu atau kabar yang dihembuskan oleh pihak-pihak tertentu.

\section{KESIMPULAN}

Hasil penelitian menunjukan bahwa mayoritas ibu mempunyai pengetahuan cukup dan mempunyai persepsi cukup tentang pelayanan kesehatan balita di masa pandemic Covid 19. Mayoritas ibu memilih untuk tidak melakukan tele konsultasi melalui media komunikasi dan menunda berkunjung ke instansi pelayanan kesehatan. Hasil analisis menunjukan ada hubungan antara pengetahuan dan persepsi terhadap pelaksanaan tele konsultasi kesehatan balita di masa pandemic Covid-19.

\section{UCAPAN TERIMAKASIH}

Ucapan terimakasih kami sampaikan kepada pemerintah kabupaten Banyumas atas kesempatan yang telah diberikan dalam penelitian ini serta kepada ibu balita yang telah berpartisipasi dalam penelitian dan kepada STIKes Muhammadiyah Gombong 
yang telah memberikan dukungan dan bimbingan dalam pelaksanaan penelitian ini.

\section{DAFTAR PUSTAKA}

Kemenkes RI. Panduan Pelayanan Kesehatan Balita Pada Masa Tanggap Darurat COVID-19. 2020

Dinkesprov. (2020) https://corona.jatengprov.go.id/data di akses tgl 2 Juli 2020.

Notoatmodjo, S. Pengantar pendidikank kesehatan dan ilmu prilaku kesehatan . Andi Offset: Yogyakarta.1993.

Notoatmodjo, S. Ilmu Perilaku Kesehatan. Jakarta: Rineka Cipta. 2014.

Darmawan A. Jurnal Dunia Kesehatan, STIKES Bina Usada Bali. Volume 5 nomor 2 2016. Diakses di https://media.neliti.com/media/publications/76442-ID-faktorfaktor-yang-mempengaruhi-perilaku.pdf tanggal 3 Mei 2020

Purnawati, N.. Faktor-Faktor Yang Mempengaruhi Kunjungan Lansia Dalam Kegiatan Posyandu Di Desa Plumbon Kecamatan Mojolaban Sukoharjo (Jurnal). Surakarta: Fakultas Ilmu Kesehatan Universitas Muhammadiyah Surakarta. 2014 Diakses di http://eprints.ums.ac.id/30723/ tanggal 2 Mei 2020

Suryaningsih. Faktor-Faktor Yang Berhubungan dengan Perilaku Kunjungan Ibu Bayi dan Balita Ke Posyandu di Puskesmas Kemiri Muka Kota Depok (Skripsi). Depok: Fakultas Kesehatan Masyarakat, Universitas Indonesia. 2012. Diakses di http://lib.ui.ac.id/file?file=digital/20319771-S-Hestri\%20Suryaningsih.pdf tanggal 2 Mei 2020 